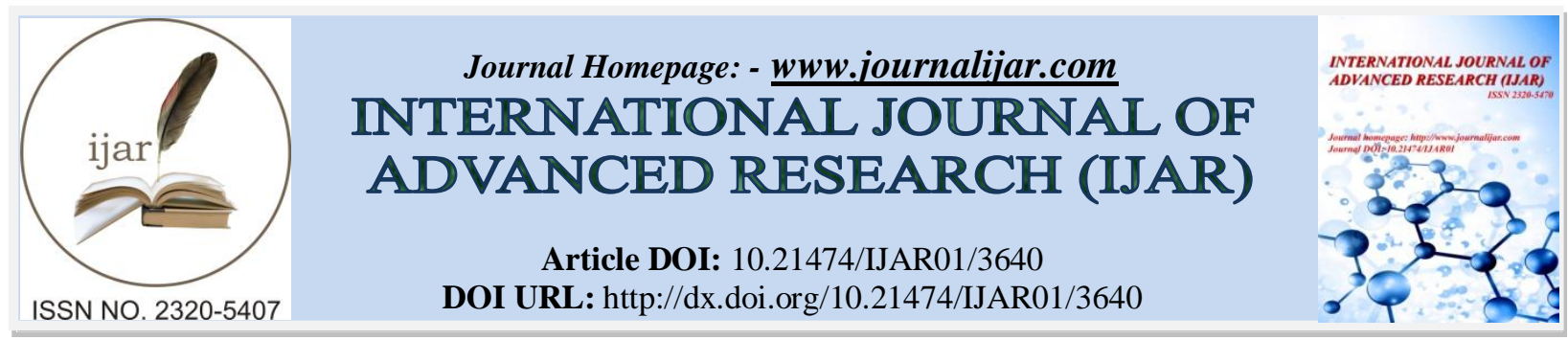

RESEARCH ARTICLE

\title{
GOING GREEN IN LITERATURE: AN INSIGHT INTO NATURE AND ECOLOGY THROUGH LITERATURE.
}

Paridhi Kishore.

Research Fellow, Department of English and Modern European Languages, University of Lucknow, Uttar Pradesh (Lucknow)

\section{Manuscript Info}

Manuscript History

Received: 08 January 2017

Final Accepted: 09 February 2017

Published: March 2017

Key words:-

Radiotherapy, Collagenase gene, cancer and Swiss mice.

\begin{abstract}
Present paper focuses on relationship between human being and nature, man being the only literary creature on earth has personified and revered the nature in its varied form, and the ecological wisdom possessed by him speaks of divine status of Mother Nature in ancient times, due to advent of technologies and ignorance, man has called upon the wrath and fury of mother nature, present paper weaves itself around the journey of human being from ecological wisdom to ecological apocalypse.
\end{abstract}

\section{Introduction:-}

Man is a part of ecosystem of earth and relies on it for its survival just like plants and animals but the superiority of man lies in the fact that he is the only literary creature of cosmos. He is unable to participate in small natural processes around the earth but with his brain he can produce enormous literature of different kind and this unique literary talent has kept him above all earthly beings. But his superiority is not independent he is closely related with other living beings for survival, this study we now refer to as ecology it studies interrelationship of living beings to one another and with their surroundings. Human ecology is the study of mankind and its response towards nature which covers all the earthly creatures. We cannot bind ecology with specific subject its appeal is universal its wisdom transcends the boundaries of various fields and manifests in any form. Ecological wisdom appeals to different cultures it manifests in romantic poetry pioneered by William Wordsworth, John Keats and PB Shelly, in pre-classical Greeks, in Zen Buddhism and many paintings.

Ecology has played a distinctive role and influenced Indian philosophy, mythology and literature. A notable feature of Indian thought towards universe is that all creation comes under one fundamental structure that is one universal spirit holds all creatures of this universe and everything has been originated from it. This is the central idea of most of the philosophical discourses of Indian literature, be it Vedas, Mahabharata, Ramayana. Apart from this, this philosophical treatise also teaches us compassion towards all life forms. The doctrine of Ahimsa and compassion towards all living being has been praised and propagated by Buddha in his teachings and sermons. It also held esteemed position in other religions. We can clearly realize that early man and nature were co-existed together in most comfortable way. Indian sages offered their reverences to the supreme which they believe existed in form of water, mountain, fire, trees etc. They revered them consider them as gods and unknowingly giving a way to sustainable development in a true sense. William Wordsworth an English Romantic poet has called the nature as 'Wisdom and spirit of Universe' he gave various stages of his love towards nature in many of his poems like Tintern 
Abbey, Exurision and The Prelude. Wordsworth two famous poems The Tables Turned and Education of Nature are wonderful example of his love for nature. And here I quote the very famous lines from The Tables Turned.

One Impulse from a vernal wood

May teach you more of man;

Of moral evil and of good

Than all the sages can.

According to the teachings of 'Atharva Veda' Nature is sacred it has to be understand as a friend, revered as mother and nurtured as a beloved child. Man is not separate from earth and universe the idea of dependent co-arising is the central theme of Buddhism, it propagates the idea of interconnectedness it suggests we are all interwoven thread in the complex structures of life. All things are interconnected according to Native American chief Seattle who says 'The earth is our mother. Whatever befalls the earth befalls the sons of earth. If man spits upon the ground they spits upon themselves. All the things are connected like blood which unites one family'. But unfortunately the human beings in this age became deaf and dumb and fail to understand such noble emotions. The brain through which human beings has mastered all other earthly creatures is now provoking him to evaluate plan and execute such manoeuvres which are disastrous for nature and natural existence. He is responsible for destruction and in turn invites the fury of nature. He is deeply engrossed in all the worldly pleasures and forgot about the management and utility of nature in a proper manner. A brilliant example of man's merciless destruction of nature is visible in Ted Huges poem Revenge Fable.

There was a person

Could not get rid of his mother

As if he were her topmost twig

So he pounded and hacked at her

With numbers and equations and laws

He investigated incriminated

And penalized her, like Tolstoy,

Forbidding, screaming and condemning,

Going for her with a knife,

Obliterating her with disgusts

Bulldozers and detergents

Requisition and central heating

Rifles and whiskey and bored sleep

With all her babes in her arms, in ghostly weepings,

She died.

The need of hour is to practice unconditional love towards nature and this will help to change the world into a better place. The power and capacity to being in love is limitless and to fall in love with nature is a true blessing because nature always gives you back treasures of joy, bliss and happiness. Alice walker portrays this sentiment in her novel The Color Purple.

My first step away from the old white man was tree. Then air, then birds, then other people but one day when I was sitting quite and feeling like a motherless child, which I was, it come to me that feeling of being part of everything, not separate at all. I knew if I cut a tree, my arm would bleed. And I laughed and I cried and I ran all around the house. I knew just what it was. In fact when it happens you can't miss it... (167).

We should cultivate such emotions to feel the pain of nature. But the modern technologies and mechanization has blinded us and right from elite class every common man has held in its grip. And the greed to get more comfort has led to the serious damage of our biological environment leading to serious catastrophic consequences. Literary studies have played major role in dealing with these difficult issues related to environment. It was in mid eighties environmental literary studies came in existence. It was Joseph Meeker who introduced the term 'Literary Ecology' in the Comedy of Survival which is an attempt to analyze the role played by literature in ecology. It basically represents the man's relationship and responses towards nature. Literary theory in general examines relation between writer text with the culture and world. Ecology analyzes the interconnectedness sentiment therefore both ecology and literature emphasize on relationships interconnectedness. The sentiment of inter texuality in literature is similar with the interconnected sentiment in the ecology. And one of the major responsibilities of literature is to 
inculcate the sense of compassion in human beings towards nature. Eco criticism refers to the study of relationship between literature and environment it shows how human culture is connected to the environment. Both literary theory and ecology criticize the stance of independent and separate meaning.

The love for the nature can be seen in the writings of many classical poets like Virgil, Horace, Theocritus they all found nature soothing comforting and peaceful. Milton found nature as a refreshing a panacea for city dweller. The rise of romantic age has changed the perspective of nature in the human eyes. Romantic poets and authors of this age personified the nature in various forms and revered its beauty sometimes as a goddess sometimes as a mother, child, lover etc. They redefine nature in new dimensions. Some contemporary poets describes the beauty of natural landscapes some yearns for the lost earthly paradise so these writings plays important role in establishing environmental forums and can help in conservation of nature by arousing human emotions and compelling them to take steps. "Lamenting on mankind Emerson a noted author in his essay Nature says 'We are as much strangers in nature as we are aliens from God. We do not understand the notes of the birds. The fox and the deer run away from us; the bear and the tiger rend us" (74).

The chain which bind us together that inter-connectedness between various creature men has lost the vision to appreciate it. And modern man does not find himself in harmony with nature but he found himself as an outside force meant to dominate and conquer the nature. The modern man has lost the sense of unity, oneness with the nature that has lost its meaning. The man's lost innocence has proved disastrous for nature and he is spreading on the globe destroying and burning it. The time demands immediate full stop on this mad dance of fury and exploitation of nature by man. A well planned methodology is needed for the preservation of nature otherwise within no time man will see the fury of nature casting its doom on civilization which he proud on the day of Apocalypse is not far away.

\section{Work Cited:-}

1. Emerson, R. (2009). Essays. Waiheke Island: Floating Press. Print.

2. Meeker, J. (1997). The comedy of survival: Literary ecology and a play ethic (3rd ed.). Tucson: University of Arizona Press. Print.

3. Phillips, D. (2003). The truth of ecology nature, culture, and literature in America. Oxford:

4. OUP. Print.

5. Walker, A. (1982). Colour purple. Orlando: Harvest Book. Print. 